\title{
Bioestimulantes in the Agriculture
}

ISSN: 2637-7659

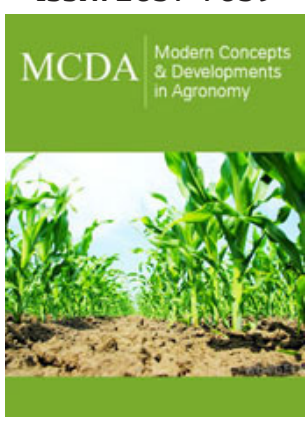

*Corresponding author: Josilaine Gonçalves da Silva, Universidade Federal de Mato Grosso, Number 2367 - district Boa Esperança, 78060-900, Cuiabá, MT, Brazil

Submission: 阱 April 27, 2019

Published: 㘹August 07, 2020

Volume 7 - Issue 1

How to cite this article: Josilaine Gonçalves da Silva. Bioestimulantes in the Agriculture. Mod Concep Dev Agrono. 7(1). MCDA. 000652. 2020. DOI: 10.31031/MCDA.2020.07.000652

Copyright@ Josilaine Gonçalves da Silva, This article is distributed under the terms of the Creative Commons Attribution 4.0 International License, which permits unrestricted use and redistribution provided that the original author and source are credited.

\author{
Josillaine Gonçalves da Silva* \\ Universidade Federal de Mato Grosso, Brazil
}

\begin{abstract}
The great challenge of modern agriculture is in the sustainable production of food without compromising natural resources. Various technologies to increase productivity have been used in agriculture, biostimulants are increasingly available in a variety of formulations and with varied ingredients on the market, therefore, there is a need for studies on agronomic benefits to ensure the viability of use in the most diverse cultures.
\end{abstract}

Keywords: Biofertilizers; Seaweed extracts; Humic substances

\section{Introduction}

Biostimulants are associations that can present two or more substances that promote plant growth of a different biochemical nature, such as amino acids, nutrients, vitamins, humic substances, algae extract and microbial inoculants, and that when used in small quantities in seed treatment, applications in soil, aerial part and / or leaf, which can improve crop growth and confer tolerance to biotic and abiotic stresses [1-4]. In the scientific literature, the word biostimulant has been used widely without drawing a border between biostimulants and other widely used categories of substances applied to plants and crops: such as fertilizers and pesticides.

\section{Market}

The use of these products has grown in agriculture and our understanding of their use has been expanding considerably. The global market for biostimulants is projected to increase $11.24 \%$ per year and reached more than US \$ 2.6 billion in 2019, reaching a total of US \$ 4.9 billion by 2025, according to data released by the North American consultancy Markets and Markets [5].

\section{Mechanisms of action}

These products increase the water and nutrient absorption capacity, as well as the resistance to water stresses, allowing the best development of plants in suboptimal conditions $[6,7]$. Several studies have shown positive results from the use of these substances. The use of biostimulant had a positive effect on the speed of germination in soybean [8]. Biostimulants based on A. nodosum and Brevibacterium sp result in positive effects in most phytotechnical characteristics, being that they provided the best increase in the dry mass of the corn roots [9], and in bean seedlings were effective in promoting the initial growth [10]. Main biostimulant classes The main categories of plant biostimulants used in agriculture are:
A. humic substances,
B. complex organic materials,
C. beneficial chemical elements,
D. inorganic salts (including phosphite), 
E. seaweed extracts,

F. chitin and chitosan derivatives,

G. antiperspirants and

H. free amino acids and other substances that contain $\mathrm{N}$ [3].

Some important categories are widely recognized by scientists and farmes, Table 1 shows the main sources of "biostimulants" and examples available on the agricultural market. Humic substances (SHs) are humidified and recalcitrant organic compounds found in soil, water, sediments and organic residues $[3,11]$ acting on the physical, physicochemical, chemical and biological properties of the soil. Bioregulator is an organic, non-nutrient compound that, when applied to the plant in low concentrations, promotes, inhibits or modifies its physiological processes [2] Seaweed extract: Seaweeds are single-celled or multicellular beings that do photosynthesis.

Table 1: Main sources "biostimulants" and examples available in the agricultural market.

\begin{tabular}{|c|c|}
\hline Bioestimulant Class & Example \\
\hline Humics substances & Acidos húmicos, ácidos fulvicos \\
\hline Biorregulators & Auxina, giberilina e citocina \\
\hline Microorganisms bioactive & $\begin{array}{c}\text { Trichoderma asperellum, Bacillus } \\
\text { methilotrophicus }\end{array}$ \\
\hline Seaweed extracts & Ascophyllum nodosum, Ecklonia maxima \\
\hline
\end{tabular}

They are nourished by the active elements of the sea and contain good concentrations of mineral salts, being a natural source of macro and micronutrients and amino acids [12]. The characteristic fertilizing potential of macroalgae has been explored for many centuries, mainly by people living in coastal areas around the world $[13,14]$. In plants, the nutritional effects through supply and micro and macronutrients indicate that they act as fertilizers, in addition to other roles $[1,15,16]$. Microbial-based biostimulants have been important since the beginning of agriculture (the use of the genus Rhizobium in legumes) and current expectations include its commercialization as a way to complement crop nutrition. The beneficial effects of microorganisms on plants depend on sophisticated nutritional and chemical signaling, as well as soil and climate factors. Plant roots release sugars, organic acids, amino acids and phenolics, which affect the composition of rhizospheric communities, leading to beneficial relationships [16].

\section{Final considerations}

Biostimulants are products with the potential to improve the resistance of plants to biotic and abiotic stresses, however little is known about its mechanism of action. There is still much to be done in this field, since a good understanding of these mechanisms can result and a more efficient generation of biostimulants for the farmer.

\section{References}

1. Calvo P, Nelson L, Kloepper JW (2014) Agricultural uses of plant biostimulants. Plant Soil 383: 3-41.

2. Castro PRC, Carvalho MEA, Mendes ACCM, Angelini BG (2017) Manual of plant stimulants: nutrients, bioregulators, biostimulants, bioactivators, phosphites and bioefertilizers in tropical agriculture. SP: Agronômica Ceres, São Paulo, Brazil, p. 453.

3. Du Jardin P (2015) Plant biostimulants: definition, concept, main categories and regulation. Scientia Horticulturae 196: 3-14.

4. Van Oosten MJ, Pepe O, Pascale S, Siletti S, Maggi A (2017) The role of biostimulants and bioeffectors as alleviators of abiotic stress in crop plants. Chemical and Biological Technologies in Agriculture 4: 5.

5. Anonymous (2013) Biostimulants market-by active ingredients, applications, crop types \& geography-global trends \& forecasts to 2018.

6. Vasconcelos ACF (2006) Use of biostimulants in corn and soybean crops. 112f, Thesis (Doutorado em Solos e Nutrição de Plantas)- (PhD in Soils and Plant Nutrition)-Postgraduate course in agronomy, School of Agriculture Luíz de Queiroz, University of São Paulo, SP, Brazil.

7. Castro GSA, Bogiani JC, Silva MG, Gazola E, Rosolem CA (2008) Treatment of soybean seeds with insecticides and a biostimulant. Brazilian Agricultural Research 43(10): 1311-1318.

8. Santos VM, Melo AV, Cardoso DP, Goncalves AH, Varanda MAF, et al. (2013) Uso de bioestimulantes no crescimento de plantas de Zea mays L. Brazilian Journal of Corn and Sorghum 12(3): 307-318.

9. Chávez JEC, Castro GLO, Tinoco ACC, García GA, Cedeño (2019) Effectiveness of biostimulants on the initial growth of common fréjol plants (Phaseolus vulgaris L.) Journal Espanciência p. 10.

10. Santos GA, Camargo FAO (2008) Fundamentals of soil organic matter: tropical and subtropical ecosystems. Porto Alegre-Brazil.

11. Texeira NT (2015) Seaweed increases the weight of the potato. Revista Campos e Negócios, Brazil.

12. Mc Hugh DJ (2003) Guide to the Seaweed Industry. FAO Fisheries Technical Paper 441, Rome, Italy.

13. Thirumaran G, Arumugam M, Arumugam R, Anantharaman P (2009) Effect of seaweed liquid fertilizer on growth and pigment concentration of Abelmoschus esculentus medikus. American-Eurasian Journal of Agronomy 2(2): 57-66.

14. Khan W, Rayirath UP, Subramanian S, Jithesh MN, Rayorath P, et al. (2009) Seaweed extracts as biostimulants of plant growth and development. Journal Plant Growth Regulater 28: 386-399.

15. Craigie JS (2011) Seaweed extract stimuli in plant Science and agriculture. Journal of Applied Phycology 23(3): 371-393.

16. Castro RO, Contreras Cornejo HA, Rodríguez LM, Bucio JL (2009) The role of microbial signals in plant growth and development. Plantar Sinal Behav 4(8): 701-712. 